\title{
KEMAMPUAN MENULIS TEKS DESKRIPSI SISWA SEKOLAH MENENGAH KEJURUAN
}

\author{
Basyaroh Purbania, Muhammad Rohmadi, Budhi Setiawan \\ Universitas Sebelas Maret \\ E-mail: basyaroh.purbania@gmail.com
}

\begin{abstract}
Abstrak: Penelitian ini bertujuan untuk mendeskripsikan kemampuan, persentase hasil, kesulitan yang dihadapi, dan cara mengatasi kesulitan siswa dalam menulis karangan deskripsi dilihat dari aspek isi, organisasi, penguasaan kalimat efektif, kosakata, dan mekanik pada siswa kelas XI AP1 SMK Batik 2 Surakarta. Penelitian ini merupakan penelitian kualitatif deskriptif dengan menggunakan pendekatan studi kasus. Teknik pengambilan sampel yang digunakan dalam penelitian ini adalah purposive sampling. Sumber data dalam penelitian ini yaitu dokumen (karangan deskripsi siswa) dan informan (guru dan siswa). Teknik pengumpulan data dilakukan dengan analisis dokumen dan wawancara mendalam. Validitas data dilakukan dengan teknik triangulasi data, teori, dan review informan. Teknik analisis data menggunakan model interaktif, yaitu pengumpulan data reduksi data, penyajian data, dan penarikan kesimpulan. Hasil penelitian sebagai berikut. Kemampua menulis karangan deskripsi siswa masuk kategosi cukup dengan rentang nilai 61-75. Selanjutnya, persentase hasil tiap aspek meliputi aspek isi sebesar 19\%, aspek organisasi sebesar 22\%, aspek penguasaan kalimat efektif sebesar 16\%, aspek kosakata sebesar 24\%, dan aspek mekanik sebesar 19\%. Pengaruh kemampuan menulis karangan deskripsi siswa diakibatkan oleh kesulitan-kesulitan yang dihadapi siswa dalam menulis yaitu: sulit mengemukakakn ide gagasan, sulit mengembangkan kalimat, sulit menentukan ejaan yang baik dan benar, dan sulit berkonsentrasi. Adapun solusinya adalah dengan: membuat kerangka karangan, mencari sumber inspirasi, menggunakan buku pedoman Ejaan Yang Disempurnakan, dan menambah waktu belajar (latihan menulis).
\end{abstract}

Kata kunci: kemampuan menulis, karangan deskripsi, sekolah menengah kejuruan

\section{ABILITY TO WRITE DESCRIPTION TEXT OF HIGH SCHOOL VOCATIONAL STUDENTS}

\begin{abstract}
This study aims to describe ability, results percentage, difficulties faced, and how to overcome students' difficulties in writing description compositions seen from the aspects of content, organization, effective sentence mastery, vocabulary, and mechanics in class XI API SMK Batik 2 Surakarta. This study is a descriptive qualitative using a case study approach. The sampling technique used in this study is purposive sampling. The data sources in this study are documents (students' description composition) and informants (teachers and students). Data collection techniques are carried out by document analysis and in-depth interviews. Data validity is done by data triangulation techniques, theories, and informant reviews. Data analysis techniques use interactive models, namely data collection, data reduction, data presentation, and conclusion drawing. The results of the study are as follows. The ability results to be included in the category pretty good with vulnerable grades of 61-75. Furthermore, the results percentage of each aspect included the content aspect of 19\%, the organizational aspect of $22 \%$, the effective sentence mastery aspect by $16 \%$, the vocabulary aspect by $24 \%$, and the mechanical aspect by 19\%. The influence of the writing description composition ability is caused by the difficulties faced by students in writing, namely: difficult to express ideas, difficult to develop sentences, difficult to determine good and right spelling, and difficult to concentrate. The solutions are: create an outline, look for sources of inspiration, use the enhanced spelling handbook, and more time to study (writing practice).
\end{abstract}

Keywords: writing ability, description composition, vocational school

BASASTRA Jurnal Bahasa, Sastra, dan Pengajarannya

Volume 8 Nomor 1, April 2020, P-ISSN 2302-6405, E-ISSN 2714-9765 


\section{PENDAHULUAN}

Bahasa Indonesia merupakan salah satu bahasa yang perlu dan sangat penting untuk dipelajari, baik dalam pendidikan formal maupun nonformal. Sifatnya yang menyeluruh dan mencangkup banyak aspek pengetahuan, membuat bahasa ini memiliki intensitas yang tinggi dan peran yang sangat besar dalam kehidupan seharihari. Bloomfield (Pamungkas, 2012: 4) juga menambahkan bahwa bahasa memegang peranan penting dalam kehidupan manusia. Ini berarti bahwa tanpa adanya bahasa kita tidak dapat berkomunikasi atau menyampaikan isi hati kepada orang lain. Bahasa dapat diwujudkan dalam ragam tulis dan ragam nontulis (Rohmadi, 2009: 3). Jadi, apapun yang diucapkan atau tertulis akan memiliki makna bagi pembaca atau pendengarnya.

Permendiknas No. 22 Tahun 2006 tentang Standar Isi untuk Satuan Pendidikan Dasar dan Menengah menyatakan bahwa bahasa memiliki peran sentral dalam perkembangan intelektual, sosial, dan emosional peserta didik, serta merupakan penunjang keberhasilan dalam mempelajari semua bidang studi. Pembelajaran bahasa diharapkan membantu peserta didik mengenal dirinya dan lingkungannya, mengemukakan ide yang ada dalam pikirannya, berpartisipasi dalam lingkungan masyarakat, serta mengasah kemampuan imaginatif sehingga kemampuan intelektualnya dapat berkembang dengan lebih baik. Dengan demikian, siswa mampu menguasai, memahami dan dapat mengimplementasikan bahasa tersebut dalam kehidupan sehari-hari.

Saddhono dan Slamet (2014: 5) mengatakan bahwa dalam penggunaan bahasa Indonesia terdapat empat keterampilan dasar berbahasa yaitu: menyimak, berbicara, menulis, dan membaca. Keempat keterampilan tersebut saling terkait antara yang satu dengan yang lain. Dalam arti lain yang sepadan, bahasa tersebut harus memiliki bobot yang sama. Kemudian, pada kenyataanya sangatlah berbeda, banyak orang yang menganggap keterampilan menulis jauh lebih susah atau sulit dibanding keterampilan yang lain. Keterampilan menulis ialah salah satu keterampilan yang sangat baik guna melahirkan pemikiran-pemikiran yang cerdas dalam pembangunan masa depan. Lewat tulisan kita dapat mengungkapkan segala yang ada dipikiran. Ketika menulis, peserta didik akan mampu mengekspresikan pikiran dan perasaannya secara cerdas sesuai konteks dan situasi yang dialaminya. Pemikiran yang dihasilkan melalui kegiatan menulis ialah sesuatu yang benar-benar dipikirkannya. Selain itu, menulis juga harus disertai wawasan yang luas dari penulisnya, terlebih untuk tulisan yang bersifat estetis atau menampilkan unsur keindahan.

Hasil dari proses kreatif menulis biasanya disebut dengan karangan atau tulisan (Dalman, 2014: 3). Karangan sendiri ialah hasil perwujudan gagasan seseorang dalam bahasa tulis yang dapat dibaca dan dimengerti oleh pembaca (Gie, 1992: 17). Karangan dapat disajikan dalam lima bentuk atau ragam wacana: (1) narasi ialah mengisahkan suatu cerita atau kejadian; (2) deskripsi ialah menggambarkan sesuatu; (3) eksposisi ialah memaparkan informasi; (4) persuasi ialah ajakan untuk meyakinkan; dan (5) argumentasi ialah pendapat tentang sesuatu disertai bukti-bukti. Karangan deskripsi adalah karangan yang menggambarkan atau melukiskan benda atau peristiwa dengan sejelas-jelasnya sehingga pembaca seolah-olah melihat, merasakan, mencium dan mendengarnya. Karangan jenis ini bermaksud memberikan kesan kepada 
pembaca sehingga pembaca dapat membayangkan apa yang sedang terjadi (Jauhari, 2013: 45).

Kurikukulum Tingkat Satuan Pendidikan (KTSP) di Sekolah Menengah Kejuruan (SMK) kelas XI semua jurusan menyebutkan bahwa pembelajaran menulis karangan deskripsi terdapat dalam silabus berupa Kompetensi Dasar 2.12 yaitu menulis wacana yang bercorak naratif, deskriptif, ekspositoris, dan argumentatif. Kompetensi ini mengharapkan siswa mampu menulis sebuah karangan dengan terlebih dahulu mengerti pengertian, tujuan, dan ciri-ciri karangan tersebut. Menulis karangan deskripsi juga harus memiliki kemampuan berbahasa yang baik seperti menggunakan pilihan kata yang tepat sehingga menciptakan daya khayal atau imajinasi bagi pembacanya.

Di SMK Batik 2 Surakarta, terutama kelas XI AP1 merupakan salah satu sekolah yang menggunakan Kurikulum Tingkat Satuan Pendidikan (KTSP) dan mengajarkan pembelajaran menulis. Ketika pembelajaran membuat tulisan yang baik, siswa dilatih secara terpadu untuk melakukan praktik menulis. Keberhasilan pembelajaran menulis tidak hanya dari faktor kurikulum atau lembaga. Pengajar atau guru juga harus mampu membuat pembelajaran menjadi bermanfaat dan lebih menarik.

Guru harus memiliki aspek dan skala penilaian yang berguna dalam evalusi pembelajaran untuk mengetahui kemampuan siswa dalam praktik menulis. Menulis karangan memerlukan aspek penilaian yang meliputi: (1) isi gagasan yang relevan dengan judul; (2) organisasi isi yang koheren dan kohesif; (3) penguasaan kalimat efektif; (4) kosakata meliputi pemilihan kata dan ungkapan yang tepat; dan (5) mekanik berisi tentang ejaan dan tanda baca. Dengan adanya aspek dan skala penilaian, di harapkan kualitas pembelajaran menjadi lebih baik. Widoyoko (2014: 1) menyatakan bahwa sistem penilaian yang baik akan mendorong pendidik untuk menentukan strategi mengajar yang baik dan memotivasi peserta didik untuk belajar yang lebih baik.

Berdasarkan latar belakang di atas, maka tujuan yang ingin dicapai dalam penelitian ini adalah untuk mendeskripsikan: (1) kemampuan menulis karangan deskripsi dilihat pada aspek isi, organisasi, penguasaan kalimat efektif, kosakata, dan mekanik pada siswa kelas XI SMK Batik 2 Surakarta; (2) persentase hasil kemampuan menulis karanagan deskripsi dilihat pada aspek isi, organisasi, penguasaan kalimat efektif, kosakata, dan mekanik pada siswa kelas XI SMK Batik 2 Surakarta; (3) kesulitan yang dihadapi siswa dalam menulis karangan deskripsi dilihat pada aspek isi, organisasi, penguasaan kalimat efektif, kosakata, dan mekanik pada siswa kelas XI SMK Batik 2 Surakarta; dan (4) cara mengatasi kesulitan siswa dalam menulis karangan deskripsi dilihat pada aspek isi, organisasi, penguasaan kalimat efektif, kosakata, dan mekanik pada siswa kelas XI SMK Batik 2 Surakarta.

Kusmana (2014: 17) berpendapat bahwa menulis merupakan aktivitas produktif. Untuk menghasilkan tulisan yang baik, penulis harus menguasai secara keseluruhan semua ide dalam pikiran yang akan ditulis dan mendapatkan beberapa cara untuk mengorganisasikan ide tersebut menurut struktur yang tepat. Penulis juga harus menguasai pokok masalah dan mampu menuangkan masalah ke dalam tulisan yang tepat.

Menulis deskripsi merupakan tulisan yang bertujuan memberikan perincian atau detail tentang objek. Perincian tersebut memberi pengaruh pada sensitivitas dan imajinasi pembaca atau pendengar. Tulisan deskripsi yang berhasil, dapat membawa pembaca untuk melihat, mendengar, merasakan atau mengalami langsung objek tersebut (Andayani, 2009: 36).

Penilaian sebuah karangan deskripsi tidak bisa sembarangan. Harus ada 
indikator yang dijadikan acuhan dalam pengambilan nilai. Nilai berupa kuantitas dan kualitas. Hal ini dimaksudkan untuk mengetahui seberapa besar atau seberapa mampu siswa dalam mencapai pembelajaran yang telah diperoleh. Indikator penilaian menulis sebuah karangan deskripsi memiliki lima aspek penilaian yang dimodifikasi dari Nurgiyantoro (2010: 4441) meliputi aspek isi dengan bobot 30 , organisasi dengan bobot 25, penguasaan kalimat efektif dengan bobot 20, kosakata dengan bobot 15, dan mekanik dengan bobot 10 . Adapun kriteria penilaian akan penulis tentukan menurut penjabarannya. Masingmasing aspek memiliki kategori sangat baik, baik, cukup , dan kurang.

\section{METODE PENELITIAN}

Penelitian ini dilakukan di SMK Batik 2 Surakarta. Sumber data utama dalam penelitian ini ialah dokumen (karangan kemampuan menulis deskripsi siswa dan transkrip hasil wawancara) dan informan (guru bahasa Indonesia dan beberapa siswa). Dengan subjek penelitian yaitu siswa kelas XI AP1 SMK Batik 2 Surakarta dengan jumlah 25 siswa.

Teknik pengumpulan data berdasarkan analisis dokumen dan wawancara mendalam. Analisis dokumen yang berguna untuk mengumpulkan data yang berbentuk dokumen yaitu berupa hasil karangan deskripsi siswa dan wawancara mendalam yang digunakan untuk mendapatkan informasi dari responden yaitu guru bahasa Indonesia beserta beberapa siswa kelas XI AP1. Penelitian ini menggunakan teknik analisis data model interaktif atau interactive model of analysis. Dengan tiga komponen berupa pengumpulan data, reduksi data, dan penyajian data.

\section{HASIL DAN PEMBAHASAN}

Data kemampuan menulis karangan deskripsi terdiri dari 25 karangan siswa. Sebagian besar siswa sudah mampu memahami konsep karangan deskripsi. Pemaparannya sebagai berikut. Pertama, dilihat dari aspek isi, kategori sangat baik berjumlah 13 siswa atau 52\%, kategori baik berjumlah 3 siswa atau 12\%, kategori cukup berjumlah 2 siswa atau $8 \%$, dan kategori kurang berjumlah 7 siswa atau $28 \%$. Pemaparannya di gambarkan pada diagram berikut.

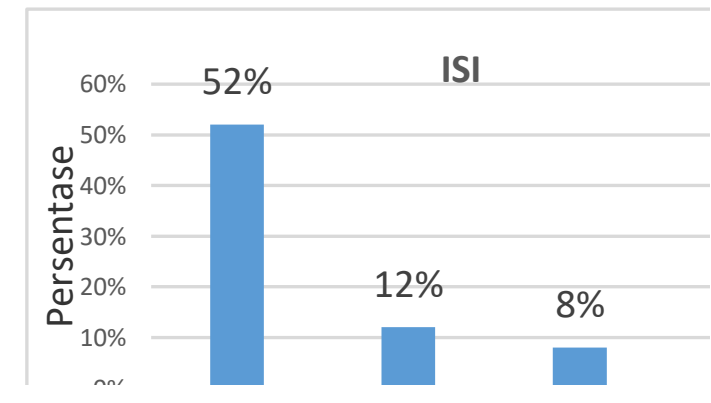

Gambar 1. Kemampuan Menulis Deskripsi Aspek Isi

Analisis data menulis karangan deskripsi siswa ditemukan dalam kode W5 (Wacana 5) dengan kategori sangat baik. Karangan tersebut berjudul Taman Balekambang. Dengan penjabaran paragraf sebagai berikut: (1) deskripsi tempat dan kondisi Taman Balekambang; (2) deskripsi fasilitas di Taman Balekambang; (3) deskripsi hewan yang ada di Taman Balekambang. Semua paragraf dalam karangan tersebut hasilnya relevan. Topik paragraf mewakili judul yang ada.

Kedua, dilihat dari aspek organisasi, kategori sangat baik berjumlah 11 siswa atau 44\%, kategori baik berjumlah 8 siswa atau 32\%, kategori cukup berjumlah 5 siswa atau 20\%, dan kategori kurang berjumlah 1 siswa atau 4\%. Pemaparannya di gambarkan pada diagram berikut. 


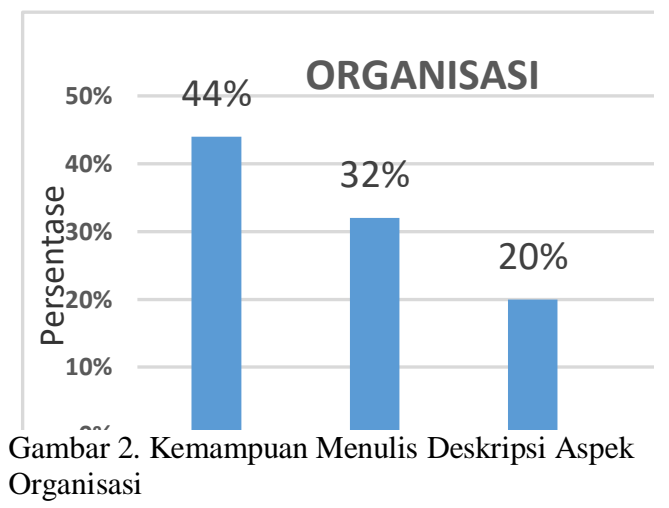

Analisis data menulis karangan deskripsi siswa ditemukan dalam kode W4 (Wacana 4) dengan kategori baik. Karangan tersebut berjudul Si Kota Padat. Terdapat satu paragraf yang kalimat satu dengan lainnya tidak padu. Seperti contoh pada paragraf kedua karangan tersebut.

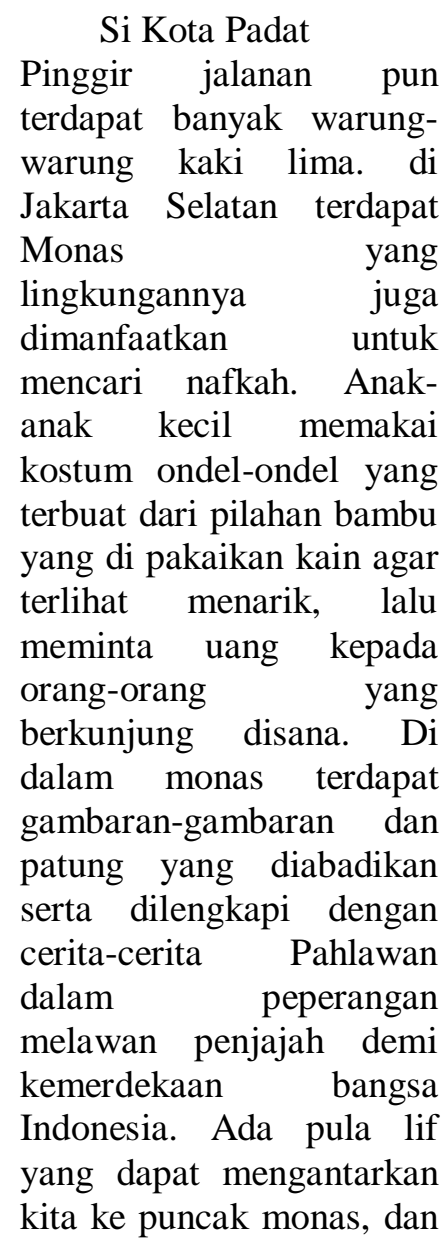

kita bisa melihat pemandangan disekeliling monas dan Kota Jakarta.

Pada contoh paragraf di atas, dalam satu paragraf membahas tentang Monas, namun kalimat pertama membahas tentang pedagang kaki lima di pinggir jalan. Kesalahan tersebut terdapat pada paragraf keempat kalimat pertama. Lebih baik kalimat tersebut dihilangkan saja. Paragraf lainnya secara keseluruhan sudah kohesi dan koheren sehingga menjadi wacana yang utuh.

Ketiga, dilihat dari aspek penguasaan kalimat efektif, kategori sangat baik berjumlah 5 siswa atau 20\%, kategori baik berjumlah 6 siswa atau 24\%, kategori cukup berjumlah 8 siswa atau 32\%, dan kategori kurang berjumlah 6 siswa atau $24 \%$. Pemaparannya di gambarkan pada diagram berikut.

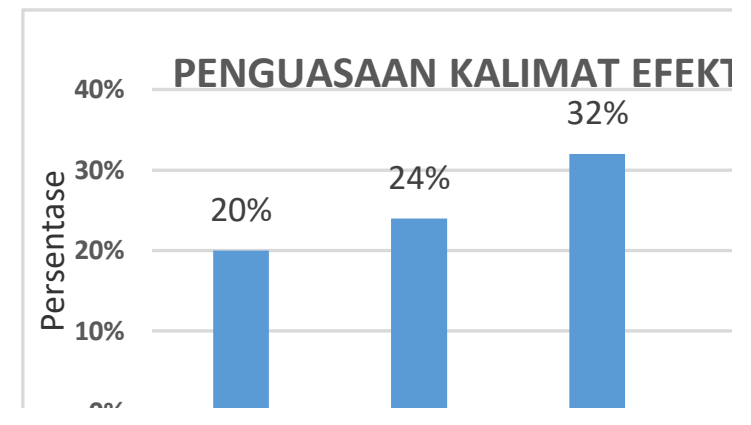

Gambar 3. Kemampuan Menulis Deskripsi Aspek Penguasaan Kalimat Efektif

Analisis data menulis karangan deskripsi siswa ditemukan dalam kode W18 (Wacana 18) dengan kategori cukup. Karangan tersebut berjudul Kota Tua. Tersapat 8 kesalahan dalam penguasaan kalimat efektif. Kesalahan tersebut disebabkan oleh kalimat tidak hemat, kalimat tidak logis, dan kalimat tidak padu. Contoh: Gemerlap berganti trafic light membuat suasana menjadi sangat tertib (W18P1K4). Pembenaran kalimat tersebut menjadi: Jalanan menjadi tertib karena traffic light.

Keempat, dilihat dari aspek kosakata, kategori sangat baik berjumlah 
16 siswa atau 64\%, kategori baik berjumlah 6 siswa atau 24\%, kategori cukup berjumlah 3 siswa atau $12 \%$, dan kategori kurang berjumlah 0 siswa atau

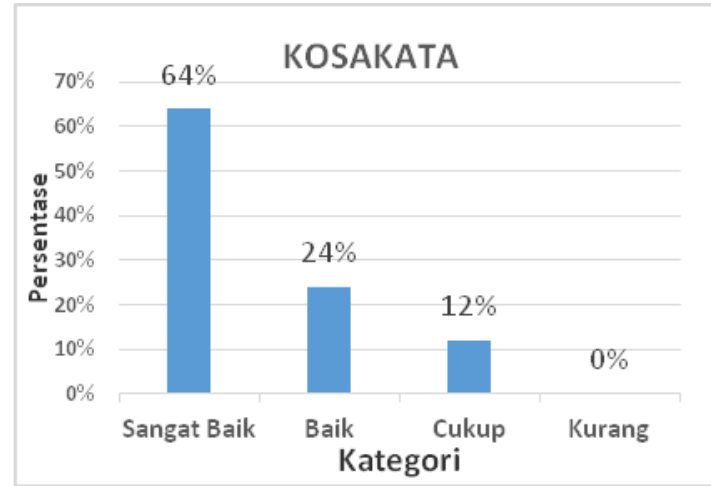

Gambar 4. Kemampuan Menulis Deskripsi Aspek Kosakata

Analisis data menulis karangan deskripsi siswa ditemukan dalam kode W9 (Wacana 9) dengan kategori baik. Karangan tersebut berjudul Rahasia Kota Jakarta. Terdapat 3 pilihan kosakata atau diksi. Pemilihan tersebut masuk dalam kategori istilah asing, sinonim, dan konotasi. Contoh: Panorama (W9P1K2) merupakan istilah asing yang berarti pemandangan alam yang bebas dan luas, polusi (W9P3K1) merupakan sinonim dari pencemaran lingkungan, dan cahaya kehidupan (W9P4K1) merupakan konotasi dari pekerjaan.

Terakhir, dilihat dari aspek mekanik, kategori sangat baik berjumlah 5 siswa atau 20\%, kategori baik berjumlah 14 siswa atau $56 \%$, kategori cukup berjumlah 4 siswa atau $16 \%$, dan kategori kurang berjumlah 2 siswa atau $8 \%$. Pemaparannya di gambarkan pada diagram berikut.
0\%. Pemaparannya di gambarkan pada diagram berikut.

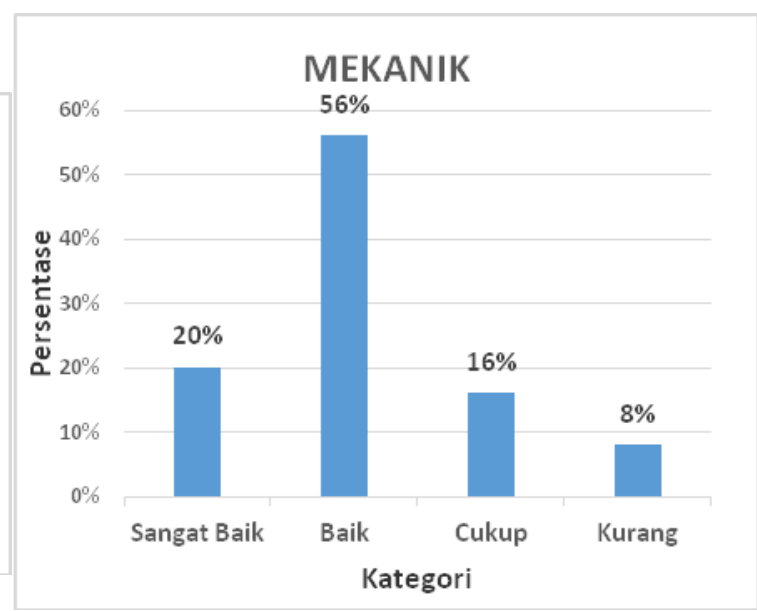

Gambar 5. Kemampuan Menulis Deskripsi Aspek Mekanik

Analisis data menulis karangan deskripsi siswa ditemukan dalam kode W19 (Wacana 19) dengan kategori kurang. Karangan tersebut berjudul Kota Jakarta. Contoh: a. Kota jakarta sangat besar dan indah (W19P1K1). Huruf pertama nama khas geografis harusnya menggunakan huruf kapital. Tanda titik (.) digunakan untuk menandai sebuah kalimat; dan b. Pemandangan disana enak sekali... (W19P1K2). Kata depan di seharusnya terpisah dari kata yang mengikutinya.

Persentase dari hasil kemampuan menulis karangan deskripsi dilihat pada tiap aspek adalah sebagai berikut.

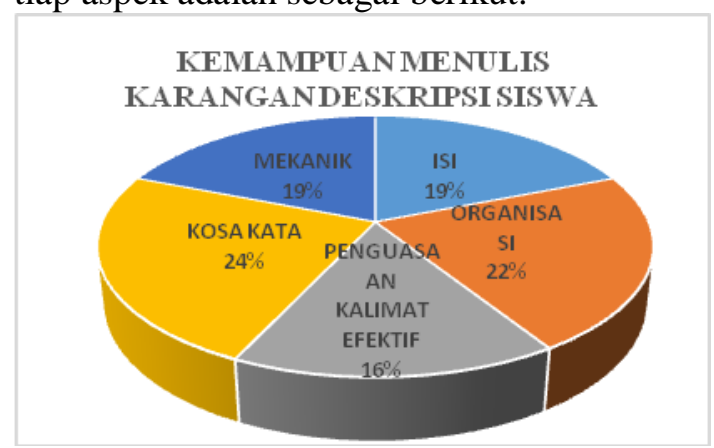

Gambar 6. Persentase Kemampuan Menulis Karangan Deskripsi Siswa 
Kemampuan hasil menulis karangan deskripsi dilihat dari aspek isi, organisasi, penguasaan kalimat efektif, kosakata, dan mekanik memiliki persentase nilai yang cukup. Kemampuan menulis karangan deskripsi dilihat dari aspek isi memiliki persentase sebesar 19\%. Kemudian, aspek organisasi memiliki persentase sebesar $22 \%$. Selanjutnya, aspek penguasaan kalimat efektif memiliki persentase $16 \%$. Setelah itu, aspek kosakata memiliki persentase sebesar 23\%. Terakhir, aspek mekanik memiliki persentase sebesar $19 \%$.

Dari data yang sudah dipaparkan dalam bentuk diagram pada temuan hasil, diperoleh kesimpulan berupa:

(1) Kemampuan menulis karangan deskripsi yang paling dikuasai adalah aspek kosakata dengan persentase $24 \%$.

(2) Kemampuan menulis karangan deskripsi yang paling tidak dikuasai adalah aspek penguasaan kalimat efektif dengan persentase $16 \%$.

(3) Nilai kemampuan menulis karangan deskripsi masuk dalam kategori sangat baik (90-100), baik (76-90), cukup (61-75), dan kurang $(\leq 60)$.

Kemampuan tersebut dipengaruhi oleh kesulitan-kesulitan yang sering dikeluhkan siswa. Kesulitan tersebut adalah: 1) siswa kesulitan dalam hal mengemukanan ide gagasan. Ide-ide yang mereka dapatkan sangat minim karena kurangnya penguasaan terhadap kerangka karangan. Banyak siswa yang lupa membuat kerangka karangan sehingga ide gagasan yang akan ditulis menjadi kurang optimal; 2) siswa kesulitan dalam hal mengembangkan kalimat. Sudah banyak kegiatan yang dilakukan misal berimajinasi namun masih sulit mengeluarkan kata-kata yang nantinya kan ditulis. Akibatnya, kalimat-kalimat tersebut menjadi kurang kohesi dan koherensi; 3) siswa sulit menentukan ejaan yang baik dan benar. Hal ini karena siswa kurang berpatok pada pedoman yang seharusnya diikuti. Ejaan yang mereka masukkan dalam bentuk tulisan menjadi kurang kompak strukturnya dan tidak logis dalam penulisan; dan 4) siswa mengeluhkan akan seringnya sulit dalam berkonsentrasi. Hal ini disebabkan karena banyak faktor seperti kelas yang gaduh sehingga membuat siswa bosan dalam mengikuti pembelajaran. Akhirnya, siswa malas menuangkan pemikirannya dalam bentuk tulisan.

Solusi untuk mengatasi kesulitankesulitan yang dihadapi siswa adalah sebagai berikut ini. Pertama, siswa membuat kerangka karangan terlebih dahulu sebelum membuat tulisan yang utuh. Kerangka karangan berguna untuk memadukan kalimat-kalimat menjadi paragraf dan memadukan paragrafparagraf menjadi karangan yang baik. Hal demikian membuat karangan menjadi kohesi dan koheren. Kerangka karangan tersebut berfungsi membuat ide lebih rinci dan urutannya lebih runtut (Sumarwati, 2019).

Kedua, siswa mencari sumber inspirasi yang banyak. Inspirasi yang banyak dan baik perlu adanya konsentrasi yang lebih. Inspirasi nantinya akan siswa masukkan ke dalam bentuk tulisan. Dengan inspirasi diharapkan kalimatkalimat yang sulit dikembangkan menjadi berkembang. Inspirasi juga bisa didapatkan dari seberapa sering siswa membaca. Kesimpulannya, inspirasi yang baik berbanding lurus dengan kalimat yang akan dikembangkan.

Ketiga, siswa menggunakan buku pedoman Ejaan Yang Disempurnakan (EYD). Pedoman Ejaan Yang Disempurnakan menjadi acuhan dalam menentukan kalimat-kalimat efektif. Kalimat-kalimat efektif yang hemat, logis, dan memiliki struktur yang kompak. Ejaan tersebut sudah sering dijadikan referensi 
yang baik dalam membuat tulisan atau karangan.

Keempat, siswa menambah waktu latihan dan belajar menulis. Waktu yang semakin banyak dan berkelanjutan membuat siswa menjadi lebih mahir dalam menulis. Tidak hanya pembelajaran di sekolah tetapi waktu belajar di rumah juga terkesan lebih efektif. Hal ini juga harus didukung oleh guru, dimana sedikit memaksakan siswa untuk berlatih dengan memberikan tugas menulis karangan. Dengan demikian, kemampuan menulis karangan dapat dioptimalkan.

\section{SIMPULAN}

Berdasarkan hasil analisis dan pembahasan data penelitian, kemampuan menulis karangan deskripsi siswa kelas XI SMK Batik 2 Surakarta dapat disimpulkan sebagai berikut. 1) gambaran kemampuan menulis karangan deskripsi dilihat dari aspek isi, organisasi, penguaaan kalimat efektif, kosakata, dan mekanik adalah sebagai berikut. Aspek isi dalam kategori sangat baik berjumlah 13 siswa (52\%), kategori baik berjumlah 3 siswa (12\%), kategori cukup berjumlah 2 siswa (8\%), dan kategori kurang berjumlah 7 siswa (28\%). Aspek organisasi dalam kategori sangat baik berjumlah 11 siswa (44\%), kategori baik berjumlah 8 siswa (32\%), kategori cukup berjumlah 5 siswa (20\%), dan kategori kurang berjumlah 1 siswa (4\%). Aspek penguasaan kalimat efektif dalam kategori sangat baik berjumlah 5 siswa (20\%), kategori baik berjumlah 6 siswa (24\%), kategori cukup berjumlah 8 siswa (32\%), dan kategori kurang berjumlah 6 siswa (24\%). Aspek kosakata dalam kategori sangat baik berjumlah 16 siswa (64\%), kategori baik berjumlah 6 siswa (24\%), kategori cukup berjumlah 3 siswa (12\%), dan kategori kurang berjumlah 0 siswa (0\%). Aspek mekanik dalam kategori sangat baik berjumlah 5 siswa (20\%), kategori baik berjumlah 14 siswa (56\%), kategori cukup berjumlah 4 siswa (16\%), dan kategori kurang berjumlah 2 siswa (8\%); 2) persentase hasil kemampuan menulis karangan deskripsi dilihat dari aspek isi sebesar $19 \%$, aspek organisasi sebesar $22 \%$, aspek penguasaan kalimat efektif sebesar $16 \%$, aspek kosakata sebesar $24 \%$, dan aspek mekanik sebesar 19\%. Selain itu, Kebanyakan nilai keseluruhan siswa masuk dalam kategori cukup yaitu rentang nilai 61 sampai 75 ; 3) kesulitan yang dihadapi siswa dalam menulis karangan deskripsi yaitu a. siswa sulit untuk mengemukakan ide gagasan; b. siswa sulit untuk mengembangkan kalimat; c. siswa sulit menentukan ejaan yang baik dan benar; dan d. siswa sulit untuk berkonsentrasi dalam pembelajaran; dan 4) cara mengatasi kesulitan siswa dalam menulis karangan deskripsi yaitu a. siswa harus membuat kerangka karangan terlebih dahulu agar tulisan kohesi dan koherensi; b. siswa harus mencari sumber inspirasi yang banyak sehingga kata-kata yang diperoleh mampu dituangkan dalam bentuk tulisan; c. siswa harus berpedoman pada buku Ejaan Yang Disempurnakan (EYD) untuk membuat tulisan yang baik dan benar; dan d. siswa harus menambah waktu untuk latihan sehingga siswa menjadi lebih mahir dalam membuat tulisan.

Berdasarkan hasil penelitian dan simpulan yang sudah dikemukakan penulis. Penulis akan memberika saran sebagai upaya meningkatkan kualitas pembelajaran bahasa Indonesia terutama pada kemampuan menulis karangan. Saran tersebut sebagai berikut; a) pihak siswa harus memperhatikan kaidah bahasa yang baik dan benar dalam emnulis sebuah karangan sehingga tidak menimbulkan ambiguitas atau salah penafsiran atara penulis dengan pembaca. Kemudian, siswa juga harus memperluas pemahaman tentang mekanik (ejaan dan tanda baca), 
koskata, kalimat efektif, dan organisasi paragraf dengan cara membaca banyak referensi dari berbagai sumber baik dari buku perpustakaan maupun internet. Selanjutnya, siswa harus lebih aktif bertanya dalam pembelajaran terutama pembelajaran menulis sehingga penjelasan yang didapatkan dari guru dapat terserap secara optimal; b) pihak guru hendaknya memberikan pengetahuan yang terkait dengan pengusaan bahasa serta ejaan yang baik dan benar, memberikan koreksi kesalahan-kesalahan penulisan beserta

\section{REFERENSI}

Ahmad \& Hendri. (2015). Mudah menguasai Bahasa Indonesia. Bandung: CV Rama Widya.

Akhadiah, S, Maidar G. A., \& Sakura H. Ridwan. (1994). Pembinaan Kemampuan Menulis Bahasa Indonesia. Jakarta: Erlangga.

Akib, E. (2012). Brain-Sketching Technique for Descriptive Text in Improve Writing Skill at senior High School of Unismuh Makasar. Exposure Journal, 1 (1), 35-58. Diperoleh pada tanggal 21 April 2019, dari journal.unismuh.ac.id/index.php/exp osure/article/view/763/pdf

Andayani. (2009). Bahasa Indonesia. Surakarta: Panitia Sertifikasi Guru (PSG) Rayon.

Dalman. (2014). Keterampilan Menulis. Jakarta: Rajawali Pers.

Djiwandono, S. (2011).Tes Bahasa: Pegangan bagi Pengajar Bahasa. Jakarta: PT Indeks.

Enre, A.F. (1988). Dasar-Dasar Keterampilan Menulis. Jakarta: Proyek Pengembangan Lembaga Pendidikan Tenaga Kependidikan. pembenarannya, dan memberikaan pembelajaran yang berkelanjutan seperti tugas rumah yang membuat siswa belajar lebih intens; c) pihak sekolah seharusnya menyediakan koleksi perpustakaan berupa sumber-sumber pustaka seperti buku-buku yang berkaitan dengan menulis, Kamus Besar Bahasa Indonesia (KBBI), dan buku pedoman Ejaan Yang Disempurnakan (EYD) sebagai referensi yang berguna untuk mengembangkan keterampilan menulis.
Gie, T. L. (1992). Pengantar Dunia Karang-Mengarang. Yogyakarta: Liberty.

Hastuti, S. (1982). Tulis Menulis. Yogyakarta: Lukman.

Husna, L. \& Roimela, Y. (2013). An Analysis of Students' Writing Skill in Descriptive Text at Grade XI IPA1 of MAN 2 Padang. Journal English Language Teaching (ELT), 1(2), 1-16.

Jauhari, H. (2013). Terampul Mengarang: dari Persiapan hingga Presentasi, dari Kalangan imliah hingga Sastra. Bandung: Nuansa Cendekia.

Jumadirah, N. (2015). Studi Kasus Menulis Karangan Menggunakan Media Flash Card pada Siswa SD. Diperoleh pada tanggal 20 April 2016, dari http://jurnal.fkip.uns.ac.id/index.php /pgsdkebumen/article/view/1726

Keraf, George. (1981). Eksposisi dan Deskripsi. Flores: Nusa Indah.

Kusmana, S. (2014). Kreativitas Menulis. Yogyakarta: Penerbit Ombak.

Lasa, H.S. (2005). Gairah Menulis. Yogyakarta: Alinea. 
Mahsun. (2014). Teks dalam Pembelajaran Bahasa Indonesia Kurikulum 2013. Jakarta: Raja Grafindo Persada.

Mardapi, D. (2012). Pengukuran, penilaian, dan Evaluasi Pendidikan. Yogyakarta: Nuha Medika.

Masidjo. (1995). Penilaian Pencapaian Hasil Belajar siswa di Sekolah. Yogyakarta: Kanisius.

Moeloeng, L.J. (2014). Metodologi Penelitian Kualitatif. Bandung: PT Remaja Rosdakarya.

Nazir, M. (2011). Metode Penelitian. Bogor: Ghalia Indonesia.

Nggiri, A.M. (2014). Keefektifan Penggunaan Media Lagu terhadap Penguasaan Kosakata Bahasa Jerman Peserta Didik Kelas X SMA Negeri 1 Muntilan Magelang. Diperoleh pada 21 April 2019, dari https://eprints.uny.ac.id/17412/1/Ard iyati\%20May\%20Nggiri\%20092032 44038.pdf

Ningsih, S., dkk. (2007). Bahasa Indonesia Untuk Mahasiswa. Yogyakarta: Penerbit Andi.

Nurgiyantoro, B. (2010). Penilaian Pembelajaran Bahasa berbasis Kompetensi. Yogyakarta: BPFE Yogyakarta.

Pahlevi, Reza. (2013). Kemampuan Menulis Paragraf Deskripsi Siswa Berdasarkan Media Audiovisual Pada Siswa Kelas X SMA Negeri 1 Babalan Tahun Ajaran 2012/2013. Diperoleh pada 20 April 2016, dari http://library.unimed.ac.id/default.as px?tabID $=622 \&$ src $=\mathrm{k} \& \mathrm{id}=164930 \&$ rsrc $=/$ default.aspx $?$ tabID $=52 \&$ jdl $=\&$ prang $=$ Pahlevi

Permendikbud Nomor 104 Tahun 2014 tentang Penilaian Hasil Belajara oleh Pendidik pada Pendidikan dasar dan Pendidikan Menengah. Diperoleh pada tanggal 20 April 2016, dari http://luk.staff.ugm.ac.id/atur/bsnp/P ermendikbud104-

2014PenilaianHasil Belajar.pdf

Permendikbud Nomor 50 Tahun 2015

tentang Pedoman Umum Ejaan

Bahasa Indonesia. Diperoleh pada tanggal 20 April 2016, dari https://www.kemdikbud.go.id/

Permendiknas Nomor 22 Tahun 2006 tentang Standar Isi untuk Satuan Pendidikan Dasar dan Menengah. Diperoleh pada tanggal 20 April 2016, dari

Pohan, A.E. (2018). The Students' Types Error on Writing Descriptive Text (An Analysis Study at Senior High School). Journal of ANGLOSAXON, 9 (1), 92-100.

Putrayasa, I.B. (2010). Kalimat Efektif (Diksi, Struktur, dan Logika). Bandung: PT Refika Aditama.

Rofi'uddin, A \& Zuhdi, D. (1999). Pendidikan Bahasa dan Sastra Indonesia di Kelas Tinggi. Jakarta: Depdikbud.

Rohmadi, M., Sugiru, E., \& Nugraheni, S. A. (2014). Belajar Bahasa Indonesia: Upaya Terampil Berbicara dan Menulis Karya Ilmiah (Cetakan Keempat). Surakarta: Cakrawala Media.

Saddhono, K. \& Slamet. Y. St. (2014). Pembelajaran Keterampilan Berbahasa Indonesia; Teori dan Aplikasi. Yogyakarta: Graha Ilmu.

Semi, M.A. (1990). Menulis Efektif. Padang: Angkasa Raya.

Setyawati, N. (2013). Analisis Kesalahan Berbahasa Indonesia: Teori dan Praktik. Surakarta: Yuma Pustaka.

Siahaan, J. (2013). An analysis of Students' Ability and Difficulties in writing Descriptive Texts. E-Journal on English Education, 1 (1), 144121. Diperoleh pada tanggal 21 april 2019

dari http://ejournal.upi.edu/index.php/LE/article/view/355/244 
Siburian, T.A. (2013). Improving Students' Achievement On Writing Descriptive Text Through Think Pair Share. International Journal of Language Learning and Applied Linguistics World, 3 (3), 32-44.

Sri, P. (2012). Bahasa Indonesia dalam Berbagai Perspektif. Yogyakarta: Penerbit Andi.

Sugiyono. (2009). Metode Penelitian Kuantitatif Kualitatif dan $R \& D$. Bandung: Alfabeta.

Sumarwati. (2019). Peningkatan Kualitas Pembelajaran Menulis melalui Pendekatan Proses pada Siswa di Kelas V Sekolah Dasar, Jurnal Logat, 6(2), 151-167.

Sutopo, H. B. (2002). Metodologi penelitian Kualitatif. Surakarta: UNS Press.

Widoyoko, S.E.P. (2014). Evaluasi Program Pembelajaran. Yogyakarta: Pustaka Pelajar.

Widyamartaya. (1990). Seni Menuangkan Gagasan. Yogyakarta: Kanisius.

Wijana, I.D.P \& Rohmadi, M. (2009). Analisis Wacana Pragmatik: Kajian Teori dan Analisis. Surakarta: Yuma Pustaka.

Wijayanti, Dkk. (2014). Bahasa Indonesia Penulisan dan Penyajian Karya Ilmiah. Depok: PT Rajagrafindo. 